\title{
Learning Achievement of UKI Students Eastern Indonesia
}

\author{
Bernadetha Nadeak
}

Christian University Of Indonesia- Jakarta

\begin{abstract}
The purpose of this research was to study the relationship between learning motivation with learning achievement.The research was conducted at the Christian University of Indonesia Faculty Student from Indonesian remote area by simple random sampling (51 samples). This study concludes that there is a significant correlation between: Learning motivation with Learning achievement. In addition, there is a significant relationship between Learning motivation with Learning achievement, if the control variables Childhood
\end{abstract}

Keyword: Learning motivation, Childhood, Learning achievement

\section{Introduction}

Learning achievement may have a meaning as the degree of relatedness of students in the teaching and learning process as an evaluation made by teachers. Student learning achievement is an assessment of the results of learning activities written in the form of number or lettersymbols and words that can show the results obtained by each student in a given period. From the description it can be concluded that learning achievement is a measure of the success of learning activities of students in mastering a number of subjects during a given period.

Learning achievement is a hope for every student who is in the course of learning process in colleges and a hope for parents/guardians and teachers.Learning achievement is an undertanding which consists of two words, namely Achievment andLearning, each of which has a different meaning. Learning achievement has been defined a lot, how far the results already obtained by a student in the mastery of tasks or subject matters received within a given period.

All perpetrators of higher education such as students, parents/sponsors and lecturers would want to achieve a good learning achievement. Good learning achievement is one indicator of the success of the learning process. In fact, however, not all students can receive a good learning achievement and there are students who get poor learning achievement. The good and bad of learning achievement obtained by students areinfluenced by various factors.

Achievement is the result of an activity of a person or group that has been done and created,and it pleaseswhen it is done. To understand the understanding of learning,there are factors influencing it, that learning is an effort for someone to obtain changes in a new behavior as a whole, as a result of their own experience in the interaction with the environment (Slameto, 2003).

As for the factors that influence the learning achievement in general include internal factors and external factors, namely:

1) Internal factors; a) physical factors include: health and disability; b) psychological factors include: Intelligence, Attention, Interest, Talent, Motivation, Maturity, Readinessand Fatigue (physical and mental).
2) External factors; a) family factors include; how parents educate,relationships between family members, home atmosphere, family's economiccondition, understanding of parents and cultural background; b) school factors include: teaching methods, curriculum, relationship between lecturers and students, relationship between students, campus discipline, learning tools, learning time,learning standards on the size, building situation, learning methods and homework; c) community factors include activities in the community, mass media, friends and forms of social life.

Factors that may create learning achievement include student interest, and the role of lecturers and staff employees of colleges that specifically require reliability in performing their duties, and one of the factors is to create job satisfaction through good management (Schermerhorn, Hunt and Osborn, 2007: 63). Similarly, someone's decisionmaking in determining learning expectations is highly influencedby factors perceived as an image of someone about something that become the focus of problems being faced. Perception highly depends on factors, among others; individuals who create the perception, the situation that occurs when the perception is formulated and disturbances which affect the formation process of the perception/target (Tampubolon, 2012: 80)

\section{The Essence of Learning Achievement of UKI students from Eastern Indonesia}

Learning achievement is a hope for every student who is in the course of learning process in colleges and a hope for parents/guardians and teachers. Learning achievement is an undertanding which consists of two words, namely Achievment and Learning, each of which has a different meaning. Learning achievement has been defined a lot, how far the results already obtained by a student in the mastery of tasks or subject matters received within a given period.

In general, learning achievement is expressed in numbers or letters to compare with one criterion. Learning achievement is the ability for students in achieving high thinking. Three aspects of learning achievement must be possessed, namely cognitive, affective and psychomotor aspects. Learning achievement is the result obtained properly by a student 


\section{International Journal of Science and Research (IJSR) \\ ISSN (Online): 2319-7064}

Index Copernicus Value (2013): 6.14 | Impact Factor (2014): 5.611

either in education or scientific fields. Students acquire the learning achievement from the results achieved by the students during the learning process.

Definition of learning achievement is the result of maximum achievement according to the student's ability at a given period on something that is learned, worked, understood and applied. All perpetrators of higher education such as students, parents and teachers would want to achieve a good learning achievement. Good learning achievement is one indicator of the success of the learning process. In fact, however, not all students can receive a good learning achievement and there are students who get poor learning achievement. The good and bad of learning achievement obtained by students are influenced by various factors.

Learning achievement is the results achieved by someone after he makes changes in learning, both at school and outside of school. In Webster's New International Dictionary; "Achievement test is a standardized test for measuring the skill or knowledge by person in one more lines of work or a study"(Webster's New International Dictionary, 1951: The meaning is a standard test to measure the skills or knowledge to a person in one or more of the lines of work or a study.

Learning achievement can be interpreted as learning results achieved when students follow and do the learning tasks and activities in a lecture. The learning achievement is mainly assessed by its cognitive aspects because it is related to the ability of students in knowledge or memory, comprehension, application, analysis, synthesis and evaluation. Student achievement is proven and demonstrated through scores or numerical values of the results of evaluation conducted by teachers against student assignments and tests or examinations they attend (Sincere, 2004).

The understanding of learning achievement is the perfection one achieves in thinking, feeling and doing (Nasution (1996). Learning achievement is said to be perfect if it meets three aspects, namely: cognitive, affective and psychomotor. On the other hand, it is said to be less satisfactory if one has not been able to meet the target in all of the three criteria.

Devi Wulansari expressed the understanding of learning achievement as a level of humanity of students in accepting, rejecting and assessing information obtained in the learning process (Wulandari, 2010). Someone's learning achievement is in accordance with the level of success in learning subject matters expressed in scores or studying report of every study field after experiencing the learning process.

Another opinion suggests that learning achievement of students is influenced by various factors, either derived from themselves (internal) or from their outside (external) (Usman, 2000). Therefore, those factors that can affect the student's learning achievement is important in order to help students achieve the learning achievement as optimally as possible in accordance with their ability.

Family economic situation is closely related to the child's learning. Children who are learning in addition to meet their basic needs, such as food, clothing, health protection and others also require learning facilities such as classrooms, desks, chairs, lighting, stationery, books and others. The learning facilities can only be met if a family has enough money.

Eastern Indonesia has poor economic situation, so that the fulfillment of basic needs and health protection are very minimum. Such a situation also directly describes inadequate learning facilities for students, so that the students seek colleges in other more developed regions such as Christian University of Indonesia which is located in Jakarta.

This, it can be concluded that learning achievement is a result or a level of ability that has been achieved by students from a learning process with the mastery of knowledge or skills and proficiency measurements in the form of scores.

\section{The Essence of Early Childhood Education (Childhood)}

Early childhood education (ECE) consists of activities and/or experience that is intended to influence the developmental changes in children before they enter a primary school. Early childhood education (ECE) program covers all types of educational programs that serve children in the preschool years and is designed to improve school performance later. In the second half of the twentieth century, the early education system in the United States grew substantially. This trend allows the majority of American children have access to some form of early childhood education (Barnett, Steven W., et al., 2003).

There are several types of programs that are early childhood education. They are also known by various names, including preschool and prekindergarten (pre-K). One of the first early childhood education initiative in the United States is the Head Start program, started in 1965. Head Start is a federal government education initiative that has given children of low-income families free access to early education. It targets children from low socioeconomic status or those eligible in several categories of risk. The Head Start program is funded by the federal Department of Health and Human Services (Pascopella, Angela. 2004).

Many early childhood education programs operate under the auspices of Title I of the Elementary and Secondary Education Act. Under Title I, local educational institutions apply to government agencies for approval of their program, and when approved, the program was later funded by the federal money. The No Child Left Behind Act (NCLB) in 2001 encourages the use of Title I, Part A funds for preschool programs, recognizing the importance of preparing children to enter school with early language, cognitive and reading skills that help them meet future academic challenges. In the academic year of 2001-2002, of approximately 300,000 children benefited from Title I services listed in preschools.

Other early childhood education programs can be run by private for the profit of company, church, or as part of a private school curriculum. These programs are usually based on education.

\section{Volume 4 Issue 11, November 2015}




\section{International Journal of Science and Research (IJSR) \\ ISSN (Online): 2319-7064 \\ Index Copernicus Value (2013): 6.14 | Impact Factor (2014): 5.611}

Since early 1990s, many countries have developed options for children of upper middle-income families to receive free preschool education. Georgia introduced the first statewide universal pre-K program, offering free early childhood education for all four years old children. New York and Oklahoma have also developed universal pre-K program, and Florida voters have approved constitutional amendments to free pre-school programs that will be available for all four years old in 2005. Almost three-quarters of children in the United States involved in some type of early childhood education. Several groups of children have higher levels of participation in early childhood education program than others. Children who live in low-income households tend to enroll in early childhood education, compared to children in families living above the poverty line. Black and white children enroll in this program in an amount higher than the Hispanic American children. Children with more educated mothers are more likely compared to other children to participate.

The importance of childhood development is that it is fundamentally the basis of human development. This stage of life is connected to the understanding, and develops moral and achieves the desired quality of life. The early years of a child's life are very important for the development of intelligence, and social behavior. Various studies on brain development proves the importance of physical ability, mental and social major. If this fundamental capability is not developed or built from an early individual's life, the potential of learning is affected. Early childhood education, with social and mental development as the basis of this learning period, will focus on children learning through play and human interaction. According to the Care and Early Childhood Education Unit, early childhood development combines incredible brain development; these years are basically laid the foundation for subsequent learning.

Early childhood education is a term used to describe general formal teaching and care of children by individuals or professionals other than their family or in settings outside the children's homes. The definition given by the National Association for the Young Children Education, early childhood education includes the children's life from birth to the age of eight years. The general definition is adopted by most cities, schools around the world will typically use an early childhood education system from birth to when a child starts attending school, which is usually at the age of five.

The definition of early childhood education is general, but the majority of school policies around the world have established a curriculum as it happens between the birth of children until they reach the age of 6 . This period is considered one of the most important in terms of child development, over the years, which is an early childhood education, indicating the most influential period of growth and development. From birth to age 6 is the period of greatest growth and development for children, at this stage, the brain develops most rapidly. During this period, children will start to walk, talk, develop themselves and describe the vision of the world. As a result of the innate development, children will build a moral foundation that is ultimately associated with the ability to perform tasks of basic education.
Early childhood education is an activity or experience that affect children developmental changes from birth to the age of six years. In this stage, the brain develops most rapidly as a result of the innate development, children will build a moral foundation that is associated with the ability to perform tasks of basic education.

\section{The Essence of Learning Motivation}

Motivation is an impulse within ourself to perform an action. Motivation is the driving force that drives and directs the activities of students. Students have a mental strength which drives the desire, attention, ability or aspirations. This driving force is motivation. Motivation arising from within will be more durable and allows to achieve better achievement. This theory was put forward by Victor $\mathrm{H}$. Vroom stated that the force motivating someone to work hard in doing their jobs depends on a reciprocal relationship between what the people want and the need from the results of that work.

According to McClelland (2009), the theory of the Need for Acievement (N.Ach) stated that the motivation is different, according to the power of one's needs for achievement. According to McClelland, the common characteristics of high achievers are three: (1) a preference for doing tasks with a moderate degree of difficulty; (2) like situations where their performance arises due to their own efforts, and not because of other factors, such as luck for example; and (3) desire feedback on their successes and failures, compared to those with low achievement.

Mc.Clelland found that achievement motive is a desire to do their best without much influenced by prestige and social, but for the sake of personal satisfaction. Meanwhile, Heckhausen in Djaali suggests that achievement motivation is a drive within the students who always strive or struggle to improve or maintain their ability as high as possible in all activities using the standard of excellence. Desires, goals, and needs in a person will be different from others. Encouragement or motivation within a person can be seen from the characteristics of the individual or the person him/herself.

The characteristics of individuals who have high achievement motivation are as follows:

1) Liking a situation or task that demands personal responsibility for the results and not on the basis of profits, fate or chance

2) Selecting realistic goals but oppose goals that are too easily to achieve or too much risk.

3) Looking for a situation or job where they obtain immediate and real feedback to determine the good or bad the results of their work.

4) Liking working alone and compete to surpass others.

5) Being able to suspend the gratification of desires for the sake of a better future.

6) Not being moved just for money, status, or other profits, they will look for them when they are an achievement institution, a measure of success (Djaali, 2008).

From the description it can be said that learning is an attempt to gain knowledge that the success is measured by achievements. 


\section{International Journal of Science and Research (IJSR) \\ ISSN (Online): 2319-7064 \\ Index Copernicus Value (2013): 6.14 | Impact Factor (2014): 5.611}

Based on the opinion, achievement motivation is the driving or moving basis for someone to do something to achieve the desired goal. Therefore, motivation is an important factor in life, especially in education and teaching. There are several forms and ways to motivate the learning activities to achieve learning achievement; (1) Giving scores; (2) Gifts; (3) Competition; (4) Ego-involvement; (5) Giving tests; (6) Knowing the results; (7) Praise; (8) Punishment; (9) The desire to learn; (10) Interest; (11) Purpose believed.

According to some opinions above shows that motivation is divided into two types, namely intrinsic and extrinsic motivation. Intrinsic motivation is motivation that comes from within a person to do something without any encouragement or external stimuli. Whereas extrinsic motivation is a motivation that comes from outside oneself and is usually driven by the environment like friends, parents, teachers, gifts, surrounding communities and so on.

Based on the description it can be said that learning is an attempt to gain knowledge that the success is measured by achievements. The encouragement of a person to learn is a form of motivation. Achievement motivation means a student has the will, the urge to move or redirect force to carry out activities that support the realization of the goal of learning, and eager to face all challenges and obstacles within a student to achieve maximum learning. High achievement is influenced by high achievement motivation the student owns.

It can be concluded that learning motivation is the driving force that causes a person to perform learning activities to achieve the learning goals desired to achieve.

Based on the background of the problem, identification of problems and restrictions of problems, the concentration of problems in this research is formulated as follows:(1) is there anyrelationship between learning motivation variables and learning achievement? (2) is there any relationship between childhood variablesand learning achievement?, and (3) there any relationship between learning motivation variables and learning achievement after being controlled by childhood variables?

\section{Research Methode}

The purpose of this research in general isto find out the correlation between learning motivation andlearning achievement of UKI student from Eastern Indonesia after being controlled by childhood variables.
The research was conducted on UKI students in Jakarta from Eastern Indonesia (IBT) as many as 51 students who were still actively studying in several study programs ("quotation sampling"), using a purposive samplingtechnique. The research was conducted for three months, namely from March 2014 until May 2014.The source of research data is students from each Study Program of Undergraduate in UKI Jakarta.

The research method is a survey method to reveal the real state of things experienced by the research sample, among others:

\section{Research Results}

\section{Data Description}

The data described in this research is summarized in the following table:

Table 1: Analysis Requirements Testing

\begin{tabular}{|c|c|c|c|c|c|c|}
\hline Var & Min Score & Max Score & Std. Dev & Mean & Median & Modus \\
\hline Y & 00 & 08 & 1.800 & 6.137 & 06 & 07 \\
\hline X1 & 1.0 & 07 & 1.655 & 6.019 & 07 & 07 \\
\hline X2 & 1.0 & 12 & 2.715 & 10.058 & 11 & 12 \\
\hline
\end{tabular}

The analysis requirements in question are those must be met in order that the regression analysiscan be done, both forthe purposes of predictionand hypothesis test. There are three requirements thatmust be metpriorto hypothesis test for regression analysis, both linear regression (simple regression) or multiple regression, namely: (1) normality requirement (Skewness and Kurtosis tests), (2) homogeneity requirement and linearity requirement. Normality requirement testing can be done using SPSS version17.0.

Table 2: SkewnessandKurtosis Tests

\begin{tabular}{|c|c|c|c|c|c|}
\hline Variable & $\mathrm{n}$ & $\begin{array}{c}\text { Skewness } \\
\text { Std. Error }\end{array}$ & $\begin{array}{c}\text { Kurosis } \\
\text { Std. Error }\end{array}$ & $\begin{array}{c}\text { Ratio } \\
\text { "p" }\end{array}$ & $\begin{array}{c}\text { Normality } \\
-2<" p ">2\end{array}$ \\
\hline $\begin{array}{c}\text { Y = Learning } \\
\text { Achievement }\end{array}$ & 51 & 0.333 & 0.656 & 0.507 & Normal \\
\hline $\begin{array}{c}\text { X1= Learning } \\
\text { Motivation }\end{array}$ & 51 & 0.333 & 0.656 & 0.507 & Normal \\
\hline X2=Chillhood & 51 & 0.333 & 0.656 & 0.507 & Normal \\
\hline
\end{tabular}

Skewness and kurtosis tests for data normality is: if the Skewness std. Errorratio andKurtosis std. Error $=" \mathrm{p} "=$ 0.507 , is between -2 and +2 , then the data is said to be normally distributed. Based on the homogeneity and linearity tests in the table below can be explained as follows:

Table 3: Homogenity and Linearity of $Y$ on $X 1$ Data

\begin{tabular}{|c|c|c|c|c|c|c|c|}
\hline & & & $\begin{array}{l}\text { Sum of } \\
\text { Squares }\end{array}$ & $d f$ & $\begin{array}{l}\text { Mean } \\
\text { Square }\end{array}$ & $F$ & Sig. \\
\hline \multirow{5}{*}{$\begin{array}{c}\text { Learning } \\
\text { Achievement } * \\
\text { Learning } \\
\text { Motivation }\end{array}$} & \multirow{3}{*}{$\begin{array}{c}\text { Between } \\
\text { Groups }\end{array}$} & (Combined) & 62.404 & 6 & 10.401 & 4.593 & 0.001 \\
\hline & & Linearity & 42.014 & 1 & 42.014 & 18.554 & $0,000^{* * *}$ \\
\hline & & Deviation from Linearity & 20.389 & 5 & 4.078 & 1.801 & 0,132 \\
\hline & \multicolumn{2}{|r|}{ Within Groups } & 99.635 & 44 & 2.264 & & \\
\hline & \multicolumn{2}{|r|}{ Total } & 162.039 & 50 & & & \\
\hline
\end{tabular}




\section{International Journal of Science and Research (IJSR) \\ ISSN (Online): 2319-7064}

Index Copernicus Value (2013): 6.14 | Impact Factor (2014): 5.611

Table 4: Homogenity and Linearity of Y on X2 Data

\begin{tabular}{|c|c|c|c|c|c|c|c|}
\hline & & $\begin{array}{c}\text { Sum of } \\
\text { Squares }\end{array}$ & $d f$ & $\begin{array}{c}\text { Mean } \\
\text { Square }\end{array}$ & $F$ & Sig. \\
\hline \multirow{2}{*}{$\begin{array}{c}\text { Learning } \\
\text { Achievement } \\
\text { Chillhood }\end{array}$} & \multirow{2}{*}{$\begin{array}{c}\text { Between } \\
\text { Groups }\end{array}$} & (Combined) & 99.634 & 10 & 9.963 & 6.386 & 0.000 \\
\cline { 3 - 8 } & & Linearity & 38.776 & 1 & 38.776 & 24.854 & $0.000^{* *}$ \\
\cline { 2 - 8 } & & Deviation from Linearity & 60.859 & 9 & 6.762 & 4.334 & 0.001 \\
\cline { 2 - 8 } & Within Groups & 62.405 & 40 & 1.560 & & \\
\cline { 2 - 8 } & Total & 162.039 & 50 & & & \\
\hline
\end{tabular}

**Signifikan; Linearity is Met

Based onthe Homogeneity test with SPSS version 17.0can be conclude that the data comes from the homogeneous population and the linear for regression of $\mathrm{Y}$ on $\mathrm{X} 1$ and $\mathrm{Y}$ on $\mathrm{X} 2$ is met.

\section{CorrelationBetween Learning Motivation(X1) and} LearningAchievementOf UKI Students(Y).

Statisticalanalysis ofsimple correlationbetweenlearning motivation(X1) andlearning achievementof students(Y) isshown bythe regression equationof $\mathrm{Y}=0.803+0.554 \mathrm{X} 1$, based onthe table below.
Table 5: Simple Regression between Learning Motivation (X1) and Learning Achievement of UKI(Y) Students

\begin{tabular}{|c|c|l|c|l|l|l|}
\hline \multicolumn{2}{|c|}{} & \multicolumn{2}{|l|}{$\begin{array}{l}\text { Unstandardized } \\
\text { Coefficients }\end{array}$} & $\begin{array}{l}\text { Standardized } \\
\text { Coefficients }\end{array}$ & & \multirow{2}{*}{ Sig. } \\
\cline { 2 - 6 } & $\mathrm{B}$ & Std. Error & Beta & $\mathrm{t}$ & Sig \\
\hline 1 & \begin{tabular}{l} 
(Constant) \\
\cline { 2 - 5 }
\end{tabular} & 2.803 & 0.834 & & 3.360 & 0.002 \\
\hline & $\begin{array}{c}\text { Learning } \\
\text { Motivation }\end{array}$ & 0.554 & 0.134 & 0.509 & 4.142 & 0.000 \\
\hline
\end{tabular}

a. Dependent Variable: Learning Achievement (Y)

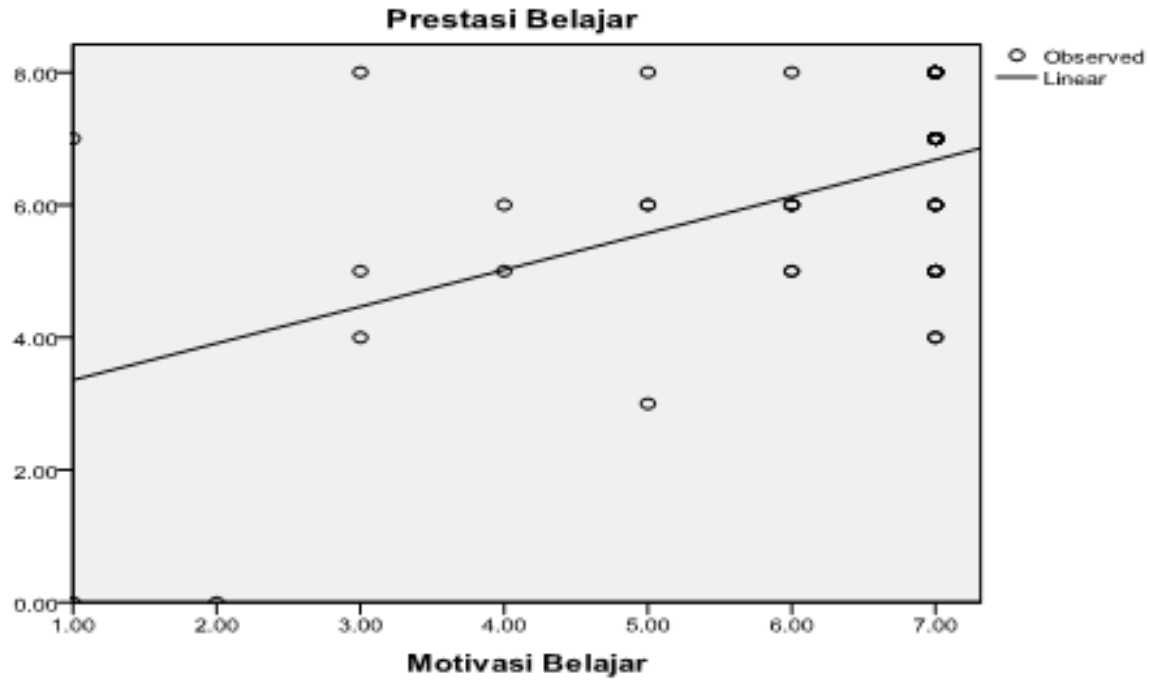

Figure 1: Regression equation $\mathrm{Y}=0,803+0,554 \mathrm{X} 1$.

Based on the significance and regression linearity tests can be concluded that the regression equation $\mathrm{Y}=0.803$ $0.554 \mathrm{X} 1$ is linear and significant. The equation indicates that every increase of 1score of Motivation(X1) resulted in an increase (0.554) to the Learning Achievement of UKI Students (Y).

Table 6: Coefficient significance test of correlation between Learning Motivation (X1) and Learning Achievement of UKI students (Y)

\begin{tabular}{|c|c|c|c|c|}
\hline Model & $\mathrm{R}$ & R Square & $\begin{array}{c}\text { Adjusted R } \\
\text { Square }\end{array}$ & $\begin{array}{c}\text { Std. Error of the } \\
\text { Estimate }\end{array}$ \\
\hline 1 & $0,509^{\mathrm{a}}$ & 0,259 & 0,244 & 1,56508 \\
\hline
\end{tabular}

The coefficient of Learning Motivation (X1) and Learning Achievement of UKI Students(Y) is equal to 0.509, whereas the strength of the correlation between Learning Motivation (X1) and Learning Achievement of UKI Students(Y) is shown by the coefficient of correlation determinant of $\mathrm{r}_{\mathrm{y}} 1=$ 0.259 which means the strength correlation of $25.90 \%$ variable $\mathrm{Y}$ variation can be explained by the $\mathrm{X} 1$ variable with the coefficient significance test of the correlation as listed in the following table.

Table 7: First Hypothesis ${ }^{\mathrm{b}}$

\begin{tabular}{|l|l|l|l|l|c|c|}
\hline \multicolumn{2}{|c|}{ Model } & $\begin{array}{c}\text { Sum of } \\
\text { Squares }\end{array}$ & $d f$ & $\begin{array}{c}\text { Mean } \\
\text { Square }\end{array}$ & $F$ & Sig. \\
\hline \multirow{2}{*}{1} & Regression & 42,014 & 1 & 42,014 & 17,152 & $0,000^{\text {a }}$ \\
\cline { 2 - 7 } & Residual & 120,025 & 49 & 2,449 & & \\
\cline { 2 - 6 } & Total & 162,039 & 50 & & & \\
\hline
\end{tabular}

It can be concluded that the firsth ypothesisis very significant because the level of significance based on the table above is $0.000<$ of the significancetest of 0.05 or 0.01 . 


\section{International Journal of Science and Research (IJSR) \\ ISSN (Online): 2319-7064}

Index Copernicus Value (2013): 6.14 | Impact Factor (2014): 5.611

Correlation Between Chillhood (X2) and Learning Achievement of UKI Students (Y)

Statistic alanalysis ofsimple correlation between Chillhood (X2) and Learning Achievement of UKI Students (Y) is shown by the regression equation $\mathrm{Y}=18.929+0$, 520X1$0.134 \mathrm{X} 3$, based on the table below.

Table 8: Regression between Chillhood (X2) with Learning Achievement of UKI Students (Y) ${ }^{\mathrm{a}}$

\begin{tabular}{|c|c|c|c|c|c|c|}
\hline \multicolumn{2}{|c|}{} & \multicolumn{2}{|c|}{$\begin{array}{c}\text { Unstandardized } \\
\text { Coefficients }\end{array}$} & $\begin{array}{c}\text { Standardized } \\
\text { Coefficients }\end{array}$ & & \\
\cline { 3 - 6 } \multicolumn{2}{|c|}{ Model } & B & $\begin{array}{c}\text { Std. } \\
\text { Error }\end{array}$ & Beta & \multirow{2}{*}{$t$} & \multirow{2}{*}{ Sig. } \\
\hline \multirow{2}{*}{1} & (Constant) & 2.876 & .860 & & 3.344 & .002 \\
\cline { 2 - 6 } & Chillhood (X2) & .324 & .083 & .489 & 3.926 & .000 \\
\hline
\end{tabular}

a.Dependent Variable: LearningAchievementof UKI Students(Y)

Statistical analysis of the correlation between Learning Motivation (X1) and Learning Achievement of UKI Students (Y) after being controlled by Childhood (X2) variable is shown by the regression equation $\mathrm{Y}=2.876+$ $0.324 \times 2$.

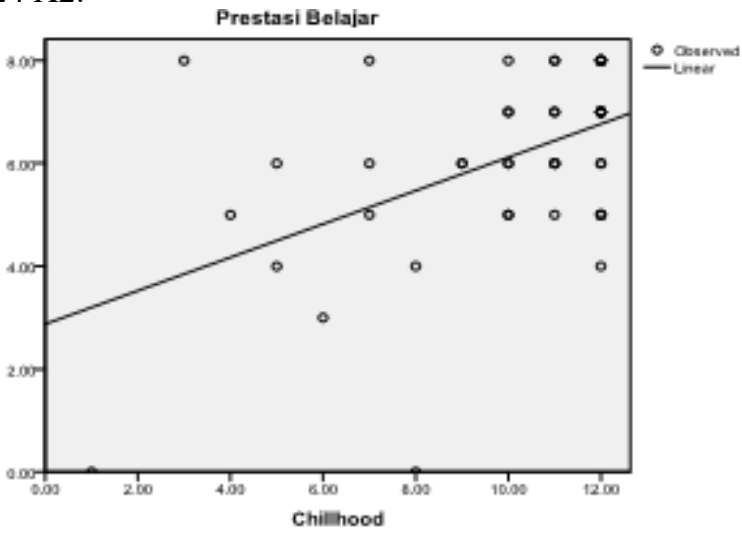

Figure 2: Regression equation $\mathrm{Y}=2.876+0.324 \mathrm{X} 2$

Table 8: Coefficient significance Test of the correlation between Chillhood (X2) and learning achievement of UKI students (Y)

\begin{tabular}{|c|c|c|c|c|}
\hline Model & $R$ & $R$ Square & $\begin{array}{c}\text { Adjusted } R \\
\text { Square }\end{array}$ & $\begin{array}{c}\text { Std. Error of the } \\
\text { Estimate }\end{array}$ \\
\hline 1 & $.489^{\mathrm{a}}$ & .239 & .224 & 1.58606 \\
\hline \multicolumn{4}{|c|}{ a. Predictors: (Constant), Chillhood } \\
\hline
\end{tabular}

The coefficient of the correlation between Childhood (X2) and Learning Achievement of UKI Students(Y) is 0.489 whereas the strength of the correlation between Chillhood (X2) and Learning Achievement of UKI Students(Y) is shown by the coefficient of correlation determinant of $\mathrm{r}_{\mathrm{y}} 2=$ 0.239259 which means the strength correlation of $23.90 \%$ variable $\mathrm{Y}$ variation can be explained by the X2variable with the coefficient significance test of the correlation as listed in the following table.

Table 9: Second Hypothesis Testing

\begin{tabular}{|c|c|c|c|c|c|c|}
\hline \multicolumn{2}{|c|}{ Model } & $\begin{array}{c}\text { Sum of } \\
\text { Squares }\end{array}$ & $d f$ & $\begin{array}{c}\text { Mean } \\
\text { Square }\end{array}$ & $F$ & Sig. \\
\hline \multirow{2}{*}{1} & Regression & 38.776 & 1 & 38.776 & 15.414 & $.000^{\mathrm{a}}$ \\
\cline { 2 - 7 } & Residual & 123.264 & 49 & 2.516 & & \\
\cline { 2 - 7 } & Total & 162.039 & 50 & & & \\
\hline \multicolumn{6}{|c|}{ a. Predictors: (Constant), Chillhood (X2) } \\
\hline
\end{tabular}

Table 10: Coefficient significance test of correlation between Learning Motivation (X1) and Learning Achievement of UKI students (Y) after being controlled by Childhood variable (X2)

\begin{tabular}{|c|c|c|c|}
\hline & & $\begin{array}{c}\text { Learning } \\
\text { Achievement } \\
(Y)\end{array}$ & $\begin{array}{c}\text { Learning } \\
\text { Motivation } \\
(X 1)\end{array}$ \\
\hline \multirow{2}{*}{$\begin{array}{c}\text { Learning } \\
\text { Achievement } \\
(Y)\end{array}$} & Pearson Correlation & 1 & $0,509^{* *}$ \\
\cline { 2 - 4 } & Sig. (1-tailed) & $\mathrm{N}$ & 0,000 \\
\hline \multirow{2}{*}{$\begin{array}{c}\text { Learning } \\
\text { Motivation } \\
(\mathrm{X} 1)\end{array}$} & Pearson Correlation & $0,509^{* *}$ & 1 \\
\cline { 2 - 4 } & Sig. (1-tailed) & 0,000 & 51 \\
\cline { 2 - 4 } & $\mathrm{N}$ & 51 & 51 \\
\hline ** A very significant correlation \\
\multicolumn{4}{|c|}{} \\
\hline
\end{tabular}

The coefficient of the correlation between Learning Motivation(X1) and Learning Achievement of UKI Students (Y) before being controlled by childhood variables is 0.509 whereas the strength of the correlation is shown by the coefficient of correlation determinant of $r_{y} 1=(0,509)$ ${ }^{2}=0.259$ which means the strength correlation of $23.90 \%$ variable $\mathrm{Y}$ variation can be explained by the X1variable with the coefficient significance test of the correlation as listed in the following table.

Table11: Third Hypothesis Testing Coefficient significance test of correlation between Learning Motivation (X1) and Learning Achievement of UKI students (Y) after being controlled by Childhood variable (X2)

\begin{tabular}{|c|c|c|c|c|}
\hline \multicolumn{3}{|c|}{ Control Variables } & $\begin{array}{l}\text { Learning } \\
\text { Achievement } \\
(Y)\end{array}$ & $\begin{array}{c}\text { Learning } \\
\text { Motivation } \\
(X 1)\end{array}$ \\
\hline \multirow{6}{*}{$\begin{array}{l}\text { Chillhood } \\
\text { (X2) }\end{array}$} & \multirow{3}{*}{$\begin{array}{l}\text { Prestasi } \\
\text { Belajar } \\
\text { (Y) }\end{array}$} & Correlation & 1,000 & 0.407 \\
\hline & & $\begin{array}{l}\text { Significance (1- } \\
\text { tailed) }\end{array}$ & . & 0.002 \\
\hline & & df & 0 & 48 \\
\hline & \multirow{3}{*}{$\begin{array}{c}\text { Motivasi } \\
\text { Belajar } \\
\text { (X1) }\end{array}$} & Correlation & 0.407 & 1.000 \\
\hline & & $\begin{array}{l}\text { Significance (1- } \\
\text { tailed) }\end{array}$ & 0.002 & . \\
\hline & & $\mathrm{df}$ & 48 & 0 \\
\hline
\end{tabular}

It can be concluded that the second hypothesis is very significant because thelevel of significancebased on the tableabove is $0.000<$ of the significancetest of 0.05 or 0.01 .

CorrelationBetween Learning Motivation (X1) and LearningAchievementof UKI Students (Y) after being controlled by Childhood (Y) variable

Statistical analysis of simple correlation between Chillhood(X2) and LearningAchievementof UKI Students (Y) before controlled by Chillhood (X2) is shown in the following table.

The coefficient of the correlation between Learning Motivation (X1) and Learning Achievementof UKI Students (Y) before controlled by Chillhood is declined/weakened to 0.407 whereas the strength of the correlation is shown by the coefficient of correlation determinant of ry1.2 $=(0.407)^{2}=$ 0.165 which means the strength correlation of $16,50 \%$ variable $\mathrm{Y}$ variation can be explained by the $\mathrm{X} 1$ variable

\section{Volume 4 Issue 11, November 2015}




\section{International Journal of Science and Research (IJSR) \\ ISSN (Online): 2319-7064}

Index Copernicus Value (2013): 6.14 | Impact Factor (2014): 5.611

with the coefficient significance test of the correlation as listed in the following table. Based on Table 14 above it can be concluded that the third hypothesisis significant because thelevel of significance based on the table above is $0.002<$ of the significance test of 0.05 or 0.01 .

\section{Conclusions, Implications, Recommendations}

and

\subsection{Conclusion}

1) There is a positive relationship between Learning Motivation and Learning Achievement of UKI students from Eastern Indonesia.

2) There is a positive relationship between Childhood and Learning Achievement of UKI students from Eastern Indonesia.

3) There is a positive relationship between Learning Motivation andLearning Achievement of UKI students from Eastern Indonesia, after being controlled by Childhood variablesalthough the strength of the correlation decreases.

\subsection{Implications}

Learning Achievement of UKI students from Eastern Indonesiawill beimproved by increasing the variables that affect the learning achievement variables.Based on these results of this research, there is a positive relationship between Learning Motivation and Learning Achievement of UKI students from Eastern Indonesia. Learning Motivation is very significant in improving the learning achievement of students. If the learning motivation can be further increased,the learning achievement of students will increase even more.

There is a positive relationship between Childhood and Learning Achievement of UKI students from Eastern Indonesia. So if the admissionselection program of students from Eastern Indonesiais carried out more carefully to measure the level of childhood, it will significantly encourage the learning motivation of students, which in turn will be able to increase the learning achievement even higher.

There is a positive relationship between learning motivation of students from Eastern Indonesiaand Learning Achievement ofof UKI students from Eastern Indonesia, before being controlled by Childhood variable, but the Learning Achievement ofof UKI students from Eastern Indonesiais weakened as a result of being controlled childhood variable. The understanding is that if childhood variables are managed properly, it is likely to increase the Learning Achievement ofof UKI students from Eastern Indonesiaeven higher.

\subsection{Efforts to Improve/Strengthen Internal Marketing}

Efforts to improve/strengthen the learning motivation is expected to bemaintained and enhanced in order to improve the stronger learning achievement of UKI students from Eastern Indonesia. Strengthening important to do is to givelearning motivation for students to actively follow the learning programsupervision ranging from the understanding of semester credit system, the measurement of semester credit units (SCU) to the study plan (KRS, KHS, IPS, and GPA) to improve the learning achievement of UKI students to be stronger/higher.

\section{Efforts to Improve/Strengthen Childhood}

Efforts to improve/strengthen the Childhood in relation to improving thelearning achievement of UKI students from Eastern Indonesiacan be done in one of the ways, namely: The institution and the leaders of UKI should attempt to socialize the criteria of prospective students selection in Eastern Indonesia (IBT) continuously through communication media (both using personal approach and multi-media) and also community service programs for high schools and junior high schools. The understanding is that when students and teachers in junior high or high schools know about the weakness of childhood, the school programs will be able to establish communication with the students' parents about better childhood education.

\subsection{Suggestions}

Based on the research results, conclusions and implications, the researcher proposes suggestions as follows:

1) In order to improve the learning motivation of students from Eastern Indonesia, it requires to establish communication media, both formal and non-formal to accommodate all opinions and suggestions from students. The purpose of this communication is to identify the character and the willingness of students that can be used as consideration to establish the philosophy or the work culture in thelearning organization. Good learning motivation is generated based on the agreement of all members of the organization, both between students and students, and between students and lecturers as well as students and the faculty leaders and the rector. Eventually, all student actions will be motivated and be harmony in acting in accordance with the learning mission that is a shared responsibility.

2) The most basic things in this research is that the description of the average scores ofthe learning motivation questionnaire are far below the mode, which means; in general the level of understanding of higher learning motivation can enhance thelearning achievement of students, so that other variables need to be considered to support the learning motivation in an effort to improve the learning achievement of students.

3) In order to improve childhood, it requires a socialization program to the parents of prospective students and the community (either through communication media or communityservice programs) about the importance of early childhood educationthat can develop insights into the community, especially prospective students as to be able to motivate themselves in order to improve the learningachievement.

\subsection{Recommendations}

An understanding of learning achievement of UKI students needsfor further research to look for other variables other thanlearning motivation and childhood variables. In addition, it requires sufficient time and is supported by 
adequate research costs in order for the learning achievement to be able to be generated optimally and compete in the real working world.

\section{References}

[1] A.Crow, L.Crow.. Psychologi Pendidikan. Yogyakarta: 1989

[2] Barnett, W. Steven, dan Jason T. Hustedt . Preschool : Paling Penting kelas. Kepemimpinan Pendidikan 60 (Jurnal BERKALA, April 2003: 7 , 54-57)

[3] Djaali. Psikologi Pendidikan. Jakarta: Bumi Aksara. 2008

[4] Mc Clelland, Interaksi dan motivasi belajar mengajar, jakarta : PT Raja Grafindi Persada. 2009.

[5] Nasotion, S. Berbagai Pendekatan dalam Proses Belajar dan Mengajar, Jakarta: Bumi Aksara. 1995

[6] Nasution, S. 1996. "Pengertian Prestasi Belajar'Tersedia pada http://sunartombs.wordpress.com(diakses tanggal 14$12-2010$

[7] Nurkencana. Evaluasi Hasil Belajar Mengajar. Surabaya: Usaha Nasional. 2005

[8] Usman, Nurdin. Konteks Implementasi Berbasis Kurikulum. Jakarta:PT. Raja Grafindo Persada 2002.

[9] Slameto. Belajar dan Faktor-Faktor yang Mempengaruhinya. Jakarta: Rineka Cipta. 2010

[10] Tampubolon Manahan Prof Dr. Perilaku Keorganisasian. PT. Ghalia Jakarta 20132.

[11] Tu'u,Tulus. Peran Disiplin pada Perilaku dan Prestasi Siswa.Jakarta:RinekaCipta2004.

[12] Pascopella , Angela . " Universal Pendidikan Dini : Point / Counterpoint . " Administrasi District (Agustus 2004)

[13] Robbins Stephen P., Organizational Behavior. New Jersey: Pren-Hall. 2009

[14] Sardiman. Interaksi dan motivasi belajar mengajar. Jakarta : PT RAJA Grafindo Persada. 2008

[15] SITUS WEB; " Pendaftaran di Program Pendidikan Anak Usia Dini . " Pusat Nasional untuk Statistik Pendidikan, 2002. $<$ http://nces.ed.gov/programs/coe/2002/section1/indica tor01.asp \& \# x 03E, (diakses 5 Januari 2005)

[16] Schermerhorn, John, R., James G., Hunt, Richard., Osborn, Organization Behavior 10/E Wiley John \& Sons Incorporated. USA. 2007

[17] Susan E., Jackson, Randall S. Schuler, Steve Warner, Managing Human ResourceSouth-Western CengageLearning 2009

[18] Webster's New Internasional Dictionary (Webster's New Internasional Dictionary), 1951 Werther, William B., and Keith Davis. Human Resources and PersonnelManagement. USA: McGraw-Hill Education, 1996.

[19] Wulandari. Pengaruh motivasi berprestasi dan kebiasaan belajar terhadap prestasi belajar siswa (studi pada siswa kelas II dan III Program Studi Administrasi Perkantoran di SMK BM Ardjuna 2 Malang. Skripsi: Universitas Malang. 2008. 